\section{Edward C. Banfield}

Edward C. Banfield, the George D. Markham Professor of Government Emeritus at Harvard University, died September 30, 1999. He was 82.

A 1938 graduate of Connecticut State College at Storrs (now the University of Connecticut), Banfield worked as a journalist and an analyst for the U.S. Forest Service and U.S. Farm Security Administration before returning to school in 1947. He received his Ph.D. from the University of Chicago in 1952 . He moved to Harvard in 1959 and, with the exception of a four-year appointment at the University of Pennsylvania, stayed in Cambridge until his death.

He published 16 books and dozens of articles on urban politics, urban planning, and civic culture, many of which advanced controversial theories and sparked extensive debate. During the presidency of Richard Nixon, Banfield headed the Presidential Task Force on Model Cities.

More important than relating the details of his career is answering the question, "Are his ideas current?"

I have students read Banfield's Political Influence (still the best study on Chicago machine politics), and I lecture on his ideas generally, especially from his several books on politics and planning in Chicago, the national syntheses in City Politics and Big City Politics, and internationally in The Moral Basis of a Backward Society. Banfield introduced cultural relativism to city politics by reinterpreting the "reform tradition" of 1313 E. 60th Street, which sits just across the Midway from the University of Chicago. That is, Charles Merriam and others in the 1930s helped build there the national headquarters for rational urban reform. The Merriam Center housed the International City Management Association, the Government Finance Officers Association, and a dozen more organizations. It also hosted seminars, offered con- sulting services, and maintained a major library. Thousands of local officials visited and worked over common issues. This helped "reform" city government across America, spreading the "city manager," "nonpartisanship," and "good government" movements generally.

Banfield questioned the appropriateness of this, asking, "Whose values does this promote?" He was the first social scientist to suggest that Mayor Richard J. Daley's Democratic Party organization had done some things better than the reformers. He pointed out, for instance, that the party's centralization solved some governance problems (like fragmentation of functions across overlapping governments). More generally, Banfield suggested that to label Daley "corrupt and immoral" only showed how he conflicted with the reformers' "political ethos." Daley followed a different "ethos," a distinct set of rules of the game, a cultural style stressing personal contacts and loyalty rather than official civil service-like due process. He further argued that Daley's ethos had its own ethics shared by many Catholics. In these terms, Daley was just as "moral" as the reformers; the mayor and the reformers simply marched to different cultural drummers.

Banfield's origins on a farm in upstate Connecticut, and work experience in the Chicago Planning Department may have made him more skeptical of charitable motives of "amateur politicians." By pointing out that reform was only "good" in terms of one "ethos," Banfield incurred the wrath of Protestant reformers across the country, who saw in his culturally relative analysis the destruction of their program's universal character. They were right to worry. Still, Banfield did not deny the importance of charitable concerns of upper-status persons. In fact, his work helped establish scholarly work on altruism.

Banfield's writings on Daley illustrate the way he shocked people by pressing for deeper interpretations of traditional questions about morality and government policy. During his long career, he questioned the adequacy of standard analyses of political reformers, Southern Italians, and African-Americans. Many felt he went too far when he interpreted the ethos of African-Americans in The Unheavenly City (1968) as encouraging riots "for fun and profit." This made him the target of campus radicals. While he deliberately shocked, he often later succeeded in leading people to rethink what they were truly about. More than once, this led to redefinitions of "problems" and classes of "solutions." Like his Harvard colleague Daniel Patrick Moynihan, his comments on the black family and family values so inflamed public discussion in 1968 that the topic became taboo. Over a decade later, it returned in debates over poverty and race (thanks to William Julius Wilson and Jesse Jackson, among others). More generally, family values became a major theme for politicians and their advisors like George Bush and Bill Clinton, and remains salient today.

Given the inflammatory title of his book on the Italians--The Moral Basis of a Backward Society-which he wrote after spending a year living with his wife's family in southern Italy, I was surprised to see it on sale in paperback translation in Italian airports during the 1970s. The Italians by no means dismissed the book as the complaint of an "ugly American." It became a landmark monograph that Italians regularly cite, even if they deplore their image in the mirror Banfield held up to them. They now ask why their system fosters and rewards an ethos of self-centeredness and uncivility, and how they can change their system.

Today, the debate continues with reference to the work of Robert Putnam. In Making Democracy Work, Putnam shows the south to be the un-Tocquevillian half of Italy. More recently, Putnam has extended 
this notion to the U.S., most noticeably in "Bowling Alone." These seminal analyses directly and explicitly build on Banfield's work on political culture.

Like Banfield, Putnam asks, "Where and why does Tocqueville's analysis work?" "Does local participation really generate democratic local leadership, shared values, and trust among citizens?" "What happens if you do have a New Englandstyle Tocquevillian legacy, but then participation drops?" And the debate is on. At the last meeting of the American Political Science Association, these issues were among the most actively discussed. The same topics have engaged European and Japanese political scientists.

These are hard issues that Banfield started us thinking about. They continue a University of Chicago tradition. Banfield trained there with Edward Shils. Shils translated Max Weber and created this tradition of political cultural analysis in America, passing it on to his students Edward Banficld, Gabriel Almond, Daniel Elazar, Ronald Inglehart, and others who, through their students and followers, have helped make these core concerns in our lives today.

Terry Nichols Clark University of Chicago

\section{Harry H. Eckstein}

Harry Eckstein, Distinguished Research Professor in the department of political science of the University of California, Irvine, died on June 22,1999 , of heart failure. He was one of the most prominent and respected social scientists of the second half of the twentieth century. The sweep of Eckstein's intellect and the depth of his learning were all but unique in a discipline that has experienced increasing specialization. His reputation is based, in part, on sustained, cumulative, innovative use of culture as an organizing concept for the rigorous study of politics, which revealed the bases of effective (stable) democracy and the nature of authority, and, in part, on the unusual trait of having made important, at times seminal, contributions to a host of diverse subfields of political inquiry. Moreover, he will be remembered for his critically important work on the political systems of Britain, Norway, and, in recent years, democratizing post-Soviet Russia.

Harry Eckstein was born on January 26, 1924, in Schotten, Germany. His family suffered the horror and dislocations of the Holocaust. In 1936, at the age of 12, Eckstein left for the U.S., as part of a group of 500 German youths selected for immigration on the basis of intelligence tests administered by American authorities. Although his sister, Ilsa, later escaped Germany and eventually settled in the U.S., the rest of his family perished in concentration camps. Eckstein spent his adolescent years in Columbus, Ohio.

Recognized as a brilliant student, Eckstein was awarded a scholarship to Harvard University, where he earned his bachelor of arts (1948, summa cum laude), masters (1950), and doctoral (1953) degrees in political science. World War II interrupted his undergraduate training, and he served a stint in the Pacific theater. His doctoral dissertation was published as The English Health Service (Harvard University Press and Oxford University Press, 1958). It was quickly followed by his study of the British Medical Association, Pressure Group Politics (Stanford University Press, 1958), which helped focus the field and remains one of the best examples of interest group analyses to this day.

Eckstein's Internal War (Free Press, 1964) was a truly pioneering study that drew attention to the need for (and thereby stimulated) systematic study of civil strife and revolution. Later, in a frequently reprinted 1965 article titled "On the Etiology of Internal Wars" (History and Theory 4[2]), he clearly disentangled what had been total confusion between the "preconditions" and the "precipitants" of civil strife.

In addition to substantive and theoretical contributions, epitomized by the work on the English national health service, interest groups, and internal war, Eckstein made important contributions to the methodology of comparative politics. His "Case Study and Theory in Political Science" (in Greenstein and Polsby's
1973 Handbook of Political Science) demonstrates the special utility of "crucial case studies" for testing theory, undermining the accepted wisdom in comparative research that more cases yielded better results.

By itself, the research described so far comprises a corpus of work important enough to both explain and justify Eckstein's international reputation. However, his central contribution to political science was his development of a framework for explaining effective democratic government and analyzing the nature of authority relations. His classic monograph, $A$ Theory of Stable Democracy (Princeton, 1961) sketches out the basic tenets of "congruence theory," which has become one of the most important tools for understanding democratic rule. Put in an overly simple way, the essential idea is that a country in which parentchild, teacher-student, and employeremployee relations are authoritarian cannot establish durable democratic government; developing such a regime requires establishing and fostering social authority relations which increasingly resemble democratic relationships as one moves from social units quite distant from the government (e.g., the family and primary school) to ones which are close (e.g., work organizations, voluntary associations, and political parties).

The monograph develops this basic idea and shows that it fits most extensively studied democracies. Next, Eckstein researched and published Division and Cohesion in Democracy (Princeton University Press, 1966), a case study of Norway which served as a plausibility probe for congruence theory.

On this foundation, Eckstein built his work on authority, which soon developed into a major independent endeavor. Many scholars had suggested that a rigorous, scientific study of politics could not be confined to the sphere of government, that the discipline would have to focus on an eminently political phenomenon such as influence, power or authority. Eckstein, uniquely among those who issued it, heeded this call and produced an important body of scholarship arguing that po- 